\title{
Two Preproendothelin 1 mRNAs Transcribed by Alternative Promoters
}

Luca Benatti, Loredana Bonecchi, Liviana Cozzi, and Paolo Sarmientos

Department of Biotechnology, Farmitalia Carlo Erba, 20014 Nerviano, Italy

\begin{abstract}
Endothelin-1, initially identified as potent vasoconstrictor secreted by vascular endothelial cells, was subsequently found to have many effects on both vascular and nonvascular tissues. We have identified from a human placenta cDNA library a clone (cDNA-2) which corresponds to a novel 5'-extended preproendothelin 1 (preproET-1) mRNA. Comparison with the known preproET-1 mRNA (cDNA-1), showed that the two molecules share the same coding sequence but differ in the 5'-untranslated region. Interestingly, cDNA-2 extends upstream of promoter regions previously shown to be essential for full preproET-1 expression. Primer extension and PCR analysis of human placenta RNA demonstrated the presence of additional transcription initiation sites located upstream of the previously identified preproET-1 CAP site. Moreover, the two mRNAs show different pattern of expression. To elucidate the mechanisms controlling the production of alternative transcripts we transfected COS-1 cells with a series of preproET-1 promoter deletion mutants. This analysis revealed that the human preproET-1 gene can be transcribed from a proximal and a distal promoter element which has hitherto been undetected. In addition, we demonstrate the presence of a region in the downepithelial specific expression. (J. Clin. Invest. 1993. 91:11491156.) Key words: alternative transcripts • epithelial cell-type specific $\bullet$ dual promoters $\bullet 5$-extended $\mathbf{m R N A} \cdot$ vasoconstrictor
\end{abstract}

\section{Introduction}

The 21 -amino acid peptide endothelin- 1 (ET-1 $)^{1}$ has surprisingly potent and wide ranging biologic activities. Originally isolated as a potent vasoconstrictor from the supernatant of cultured porcine aortic endothelial cells ( 1 ) it has been further identified in several other tissues (2-5). ET-1 stimulates mitogenesis in 3T3 fibroblasts, vascular smooth muscle cells and mesangial cells (6-9). It causes the release of atrial natriuretic factor from atrial and ventricular cells, activates the transcription of cardiac-specific genes $(10,11)$, inhibits the release of renin from glomeruli (12), and induces the release of tissue-

Address correspondence to Dr. Luca Benatti, Department of Biotechnology, Via Papa Giovanni XXIII, 23, 20014, Nerviano, Italy. Dr. Sarmientos's present address is PRIMM s.r.l., Via C. Flaminio 5/7, Milano, Italy.

Received for publication 1 June 1992 and in revised form 29 September 1992

1. Abbreviations used in this paper: ang II, angiotensin II; ET-1, endothelin-1; preproET-1, preproendothelin-1; 3'-UTR, 3' untranslated region.

J. Clin. Invest

(c) The American Society for Clinical Investigation, Inc.

0021-9738/93/03/1149/08 \$2.00

Volume 91, March 1993, 1149-1156 type plasminogen activator and prostanoids $(13,14)$. These findings have led to the suggestion that ET-1 may play an important role in cellular signaling mechanisms which extend beyond its well documented vasopressor effects.

Human ET-1 is derived from a 212 amino acid peptide precursor (preproET-1) encoded by a single gene located on chromosome $6(15,16)$. The human ET-1 gene consists of five exons distributed over $6.8 \mathrm{~kb}$ of genomic DNA (17). PreproET-1 includes a functional 17 amino acid signal peptide which allows the protein to enter the secretory pathway (18). BigET-1, which differs from ET-1 in having an extension of 17 amino acids at the carboxy terminus, is the largest precursor of ET-1 so far identified in vivo $(19,20)$. The existence of an endothelin-converting enzyme cleaving bigET-1 into mature 21 -amino acid peptide ET-1 has been postulated ( 1 ). Recently we demonstrated that human preproET-1 is fully processed by microinjected Xenopus oocytes (21) and recombinant baculovirus-infected insect cells (22), suggesting that common pathways of preproET-1 maturation exist among different cells. Moreover, ultrastructural analysis demonstrates that endothelial cells do not possess substantial numbers of secretory granules (23). Thus, ET-1 is probably constitutively released from cells after intracellular processing. ET-1 production and secretion may therefore be regulated at the level of mRNA transcription. Indeed, preproET-1 mRNA levels can be modulated by a variety of factors. Transforming growth factor- $\beta$ ( TGF- $\beta$ ), thrombin, and a thromboxane $\mathrm{A}_{2}$ analogue stimulate endothelin $1 \mathrm{mRNA}$ synthesis in human mesangial cells in culture (5). PreproET-1 mRNA is constitutively expressed in cultured endothelial cells and levels of transcripts are increased by angiotensin II (ang II ), TGF- $\beta$, and thrombin $(1,19)$. Furthermore, PDGF-A, TGF- $\beta$, ang II, arginine-vasopressin, and ET- 1 itself, stimulate preproET-1 mRNA transcription in rat vascular smooth muscle cells in culture (24). PreproET-1 mRNA is extremely unstable with a half-life of $\sim 15 \mathrm{~min}(17)$. The instability of preproET-1 mRNA probably results from the presence of two conserved AUUUA sequences in the $3^{\prime}$-untranslated region ( 3 '-UTR) that mediate selective mRNA degradation.

Recently, two DNA sequences in the preproET-1 gene located at position -148 to -117 (region $A$ ) and -117 to -98 ( region B) were found to be important for constitutive expression of preproET-1 gene in endothelial cells in culture (25). Moreover a GATA-like protein responsible for controlling preproET-1 gene expression at least in endothelial cells and which binds to region $\mathrm{A}$ in the preproET-1 promoter has been identified and cloned $(26,27)$.

In this paper, we describe the isolation of a novel 5'-extended preproET-1 mRNA that contains functional promoter sequences. This raises the possibility that the preproET-1 gene may be regulated by different promoters. To investigate this question we characterized the 5 '-flanking region of the human preproET-1 gene demonstrating that it can be transcribed from two alternative promoter element. Interestingly, analysis of the tissue distribution of the two mRNAs shows a tissue-type specificity for mRNA-2 in brain and heart tissues. We also identify a 
short nucleotide sequence in the downstream promoter responsible for ET-1 cell-type specific expression. Our results suggest the existence of different mechanisms controlling ET-1 gene expression in renal epithelial cells as compared to endothelial cells.

\section{Methods}

RNA preparation. Total cellular RNA was isolated by lysis in $4 \mathrm{M}$ guanidium isothiocyanate and ultracentrifugation over a $\mathrm{CsCl}$ cushion as previously described (28). Human brain and heart poly $(\mathrm{A})^{+} \mathrm{RNA}$ were from Clontech (Palo Alto, CA).

Sequencing of genomic DNA and cDNA clones. Sequences were obtained on both strands using Sequenase (United States Biochemicals Corp., Cleveland, $\mathrm{OH}$ ) and standard dideoxy sequencing methodology (29).

Cell lines and culture conditions. Eukaryotic cell culture media and sera were obtained from Gibco Laboratories (Chagrim Falls, $\mathrm{OH}$ ). COS 1 and HeLa cells were obtained from the American Type Culture Collection, Rockville, MD, were grown in DMEM supplemented with $10 \%$ fetal calf serum.

$R N A$ primer extension. Two primers: oligo 1 (5'-AGCGAGCGGAGCGTCTGCAGGCGCACGCGGCGGT-3') and oligo 2 (5'-TTATTAGTCACCAACAGGCAACGTGCAGCCG-3'), were ${ }^{32}$ P-labeled at the 5 '-end with [ $\left.{ }^{32} \mathrm{P}\right] \mathrm{ATP}$ and T4 polynucleotide kinase. $0.2 \mathrm{pmol}$ of the primer were annealed to $10 \mu \mathrm{g}$ of human total RNA or $1 \mu \mathrm{g}$ of poly $(\mathrm{A})^{+} \mathrm{RNA}$ at $50^{\circ} \mathrm{C}$ for $6 \mathrm{~h}$ in $20 \mu \mathrm{l}$ of $80 \%$ formamide, $0.4 \mathrm{M}$ $\mathrm{NaCl}, 40 \mathrm{mM}$ Pipes, $1 \mathrm{mM}$ EDTA, pH 6.4. After ethanol precipitation pellets were dissolved in $20 \mu \mathrm{l}$ of $60 \mathrm{mM} \mathrm{NaCl}, 10 \mathrm{mM}$ Tris ( $\mathrm{pH} 8.3$ ), $10 \mathrm{mM} \mathrm{DTT}, 8 \mathrm{mM} \mathrm{MgCl}$, and $1 \mathrm{mM}$ each of the dNTPs. Primer extension reactions were done at $42^{\circ} \mathrm{C}$ for $1 \mathrm{~h}$ in the presence of $10 \mathrm{U}$ of AMV reverse transcriptase (BRL, Gaithersburg, MD).

Polymerase chain reaction. $20 \mu \mathrm{g}$ of total placenta was reverse transcribed, as described for primer extension, with a specific oligonucleotide (oligo 3: 5'-AGGCGCAGGACCCGTTCGCC-3'), located within the 5'-UTR of mRNA-1 and mRNA-2. After extraction with phenol/ chloroform and ethanol precipitation, the pellet was dissolved in $40 \mu \mathrm{l}$ $\mathrm{H}_{2} \mathrm{O}$. The PCR reactions on the first stranded cDNA, were performed according to the published procedures (30). Amplification cycles were: $1 \mathrm{~min}$ at $60^{\circ} \mathrm{C}, 2 \mathrm{~min}$ at $72^{\circ} \mathrm{C}$, and $45 \mathrm{~s}$ at $94^{\circ} \mathrm{C}$.

Construction of promoter deletion mutants. Deletion mutants of the 5 '-flanking sequence of the human preproET-1 gene were obtained by PCR. This technique was used to amplify selectively DNA fragments from a plasmid containing most of the 5'-flanking region of the preproET-1 gene. In each case was used a set of primers having HindIII linkers at their 5' ends. Each fragment was amplified with a common reverse primer (5'-AGATCTCAAAGCGATCCTTCA-3') and the following sense primers: (5'-GAGCTCTGATGTTATTTTTAAGCTC3', for -647CAT); (5'-GCTGCACGTTGCCTGTTGGTG-3', for -127CAT); (5'-ACACAATAACATTGTCTGGGGCTG-3', for -99CAT); (5'-AAGTCGGAGCTGTTTACCCCCACT-3', for -70CAT) and (5'-AAGCCGGCAGAGAGCTGTCCAAT-3', for -25CAT). A different reverse primer was used (5'-CCGGAGATAAGCCAGGCCCCGA-3') in the case of $(-127 ;-647)$ construct. Amplifications were performed from $1 \mathrm{ng}$ of plasmid DNA by 30 cycles consisting of $30 \mathrm{~s}$ at $94^{\circ} \mathrm{C}, 1 \mathrm{~min}$ at $65^{\circ} \mathrm{C}$, and $1 \mathrm{~min}$ at $72^{\circ} \mathrm{C}$, as described (30). The amplified fragments were HindIII digested, purified from the gel, and inserted into the HindIII site upstream of the CAT gene of the pCAT-basic plasmid (Promega Corp., Madison, WI). The correct orientation and sequence of each deletion mutant was further confirmed.

Transfection and CAT assay. COS 1 and HeLa cells were plated on $60-\mathrm{mm}$ dishes at a density adjusted so that they reached $\sim 60 \%$ confluence after overnight incubation. $4 \mathrm{~h}$ before transfection the culture medium was replaced. Before transfection, the cells were washed three times with Hepes-buffered saline (HBS; $10 \mathrm{mM}$ Hepes [ $\mathrm{N}$-2-hydroxyethylpiperazine- $N^{\prime}$-2-ethanesulfonic acid, $\mathrm{pH} 7.3$ ], $6.7 \mathrm{mM} \mathrm{KCl}, 142$
$\mathrm{mM} \mathrm{NaCl}$ ), and transfection was carried out by the calcium phosphate coprecipitation method (31), using $10 \mu \mathrm{g}$ of plasmids. All transfections were performed in duplicate and three independent experiments for each construct. $2 \mathrm{~d}$ after transfection the cells were harvested and cell extracts for CAT enzyme assay were prepared by freezing and thawing four times in $120 \mu \mathrm{l}$ of Tris- $\mathrm{HCl} 250 \mathrm{mM} \mathrm{pH} \mathrm{7.8.} \mathrm{A} \mathrm{protein} \mathrm{assay}$ (Bio-Rad Laboratories, Richmond, CA) was used to quantitate the amount of protein in each cell extract. Aliquots of lysates, containing equal amount of protein, were assayed for CAT activity as described (31). Some experiments were carried out in the presence of a $\beta$-galactosidase reporter plasmid pSV- $\beta$ Gal (Promega Corp.), as described (25). Results obtained in the absence of this plasmid, or in its presence and normalized on the basis of its activity, were essentially identical.

\section{Results}

Isolation of a 5'-extended form of preproET-1 mRNA. A $\lambda \mathrm{gt} 11$ human placenta cDNA library was screened by plaque hybridization. Two different oligonucleotides based on the published nucleotide sequence of human preproET-1 CDNA (15) were used as probe: oligo A ( from nucleotide +1 to +27 ) and oligo $B$ (from nucleotide +600 to +627 ). 20 hybridization positives were isolated by the screening of $\sim 6 \times 10^{5}$ independent plaques and the inserts were subcloned into the EcoRI site of plasmid M13mp18. Restriction endonuclease mapping of the cDNA clones suggested heterogeneity at the $5^{\prime}$ termini of the cDNAs. Two classes of inserts consisting of $1,167 \mathrm{bp}$ (cDNA1) and 1,251 bp (cDNA-2) were identified. The entire cDNA-1 and cDNA-2 clones were sequenced in both directions. Comparison of their nucleotide sequences is shown in Fig. 1. cDNA1 corresponds to the published cDNA sequence of human preproET-1 (15). This clone, which terminates in a naturally occurring EcoRI site, lacks most of the 3'-UTR and the poly(A) tail. The whole $3^{\prime}$-UTR region of human preproET-1 was further cloned showing that it extends 849 nucleotides from the natural EcoRI site (17). Differences between the two cDNAs are present only in the 5'-UTR. In fact cDNA-2 contains an 80 -nucleotide extension at its $5^{\prime}$ end. In human endothelial cells, the $5^{\prime}$ end of preproET-1 mRNA was reported to be 268 nucleotides upstream of the translational start site (17). Interestingly, the $5^{\prime}$ leader sequence of the largest preproET-1 cDNA extended upstream of this putative transcription start site and included a TATA box element that has previously been shown to be essential for human ET-1 gene expression in endothelial cells (25).

Mapping 5' termini of preproET-1 mRNAs. To characterize the precise transcriptional start sites of the two preproET-1 mRNAs, primer extension analysis was performed. For this purpose a primer covering nucleotides (nt) +100 to $n t+67$ (oligo 1, Fig. 2), was used for extension experiments as well as to obtain the sequence ladder. In the presence of human placenta RNA a series of specific bands were obtained (Fig. $3 \mathrm{~A}$ ). Three of them confirmed the position of the preproET-1 mRNA transcriptional start site previously mapped with S1 analysis (17). Nevertheless little discrepancies were observed. Inoue and co-workers suggested that the cap site was at $\mathrm{nt}+1$ while our primer extension analysis indicated $\mathrm{nt}+2,+3$, and +4 as potential transcriptional start site. Therefore, this cap site, located a few bases upstream to the $5^{\prime}$ end of cDNA-1 was called proximal cap site (cap-1). This finding is further supported by the observation that a functional TATA box is located $\sim 30 \mathrm{nt}$ upstream this cap site. Interestingly, additional extension products, $>100 \mathrm{nt}$ upstream to the proximal cap site 
Leu Met Asp Lys Glu Cys Ual Tyr Phe Cys His Leu Asp lle lle Trp Ual Asn Thr Pro Glu His Ual Ual Pro Tyr Gly Leu CTG ATG GAT AAR GAG TGT GTC TAC TTC TGC CAC CTG GAC ATC ATT TGG GTC AAC ACT CCC GAG CAC GTT GTT CCG TAT GGA CTT *** *********************************************************************************

Gly Ser Pro Arg Ser Lys Arg Ala Leu Glu Asn Leu Leu Pro Thr Lys Ala Thr Asp Arg Glu Aan Arg Cys Gln Cys Ala Ser GGA AGC CCT AGG TCC ARG AGA GCC TTG GAG AAT TTA CTT CCC ACA AAG GCA ACA GAC CGT GAG AAT AGA TGC CAA TGT GCT AGC

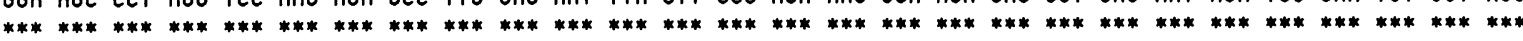

G/n Lys Asp Lys Lys Cys Trp Asn Phe Cys G/n Ala Gly Lys Glu Leu Arg Ala Glu Asp Ile Met Glu Lys Asp Trp Asn Asn CAA ARA GAC AAG AAG TGC TGG ART TTT TGC CAA GCA GGA AAA GAA CTC AGG GCT GAA GAC ATT ATG GAG AAA GAC TGG AAT AAT *** *******************************************************************************

His Lys Lys Gly Lys Asp Cys Ser Lys Leu Gly Lys Lys Cys Ile Tyr GIn GIn Leu Val Arg Gly Arg Lys Ile Arg Arg Ser CAT AAG AAA GGA AAA GAC TGT TCC AAG CTT GGG ARA ARG TGT ATT TAT CAG CAG TTA GTG AGA GGA AGA AAA ATC AGA AGA AGT *** *** **************************************************************************

Ser Glu Glu His Leu Arg GIn Thr Arg Ser Glu Thr Met Arg Asn Ser Ual Lys Ser Ser Phe His Asp Pro Lys Leu Lys Gly TCA GAG GAA CAC CTA AGA CAA ACC AGG TCG GAG ACC ATG AGA AAC AGC GTC AAA TCA TCT TTT CAT GAT CCC AAG CTG AAA GGC *** *** *** *** ***********************************************************************1

Lys Pro Ser Arg Glu Arg Tyr Val Thr His Aan Arg Ala His Trp

AAG CCC TCC AGA GAG CGT TAT GTG ACC CAC AAC CGA GCA CAT TGG TGACAGACTTCGGGGCCTGTCTGAAGCCATAGCCTCCACGGAGAGCCCTGT

**************************************************************************************************

Figure 1. Sequences of cDNA-1 and cDNA-2 clones. The upper line represents the sequence of cDNA-2; the lower line represents the cDNA-1 sequence. *Indicates the same nucleotide. The TATA box element of the known preproET-1 promoter is included in the cDNA-2 sequence (underlined). Cap (nucleotide +1 ), represents the position of the previously mapped transcription start site of the human preproET-1 gene (17). A naturally occurring EcoRI site is located at the $3^{\prime}$ end of both cDNAs.

were detected. To locate more precisely the positions of these other potential cap sites a primer covering $\mathrm{nt}-99$ to $\mathrm{nt}-129$ (oligo 2, Fig. 2), and positioned upstream to the $5^{\prime}$ end of cDNA-2 was used. Elongation of this primer on total human placenta RNA yielded a series of bands (Fig. $3 B$ ) suggesting the existence of multiple transcriptional start sites upstream to the functional CAAT and TATA boxes of the preproET-1 promoter region (25). As control also yeast tRNA was reverse transcribed either with oligo 1 and oligo 2, demonstrating the specificity of the extension products obtained with placenta RNA (not shown). To verify whether these multiple cap sites are located to an alternative $5^{\prime}$ exon or are directly upstream to the $5^{\prime}$ end of cDNA-2, PCRs were performed with total placenta RNA. One of the primers, covering nt +44 to nt +24 , (oligo 3, Fig. 2) was invariant and was used as antisense oligo; the other two were positioned in such a way that one (oligo 4) 
had its $5^{\prime}$ last base in correspondence of the $n t-226$, previously identified as the upstream cap site, while the other (oligo 5) had its $3^{\prime}$ last base in the correspondence of the same nucleotide. As shown in Fig. 4 only oligo 4 gives a product of the expected size ( $300 \mathrm{bp}$ ), lane 3; while oligo 5 does not amplify any band, lane 2. To exclude that the amplified product was due to the presence of contaminating recombinant DNA in the reverse transcription mixture a control experiment was performed. Half of the aliquot of human placenta RNA was treated with RNAse before reverse transcription reaction and processed as the other sample. As shown in Fig. 4, lane 1, oligo 4 does not amplify any band in the RNase pretreated sample. From these results it seemed very likely that at least two preproET-1 mRNA species are synthesized at least in human placenta tissues: one, mRNA-1, having its 5 ' end corresponding to cap-1, while the other, mRNA-2, which probably belongs to a class of 5'-extended mRNAs, having their $5^{\prime}$ end in a region located 200 $300 \mathrm{nt}$ upstream to cap-1.

Two preproET-1 gene promoters. Based on our studies we proposed that human preproET-1 gene contains two promoter elements controlling the transcription of mRNA-1 and mRNA-2. If this hypothesis is correct the region upstream to mRNA-2 must exhibit promoter activity. Before to test this hypothesis we decided to better localize functional promoter activity within the 5 '-flanking region of the preproET-1 gene. Therefore, we planned to clone the human preproET-1 gene. For this purpose, a human genomic DNA library constructed in $\lambda$ EMBL3 (Clontech) was screened using human preproET1 cDNA- 1 as probe. From $\sim 10^{6}$ clones we isolated three recombinants. One of them, $\lambda 4.1$, showed the same nucleotide sequence of the human preproET-1 gene previously isolated $(16,17)$. To assess promoter activity the 1,675-bp EcoRIBgliII genomic fragment of $\lambda 4.1$, which includes $n t-1505$ to

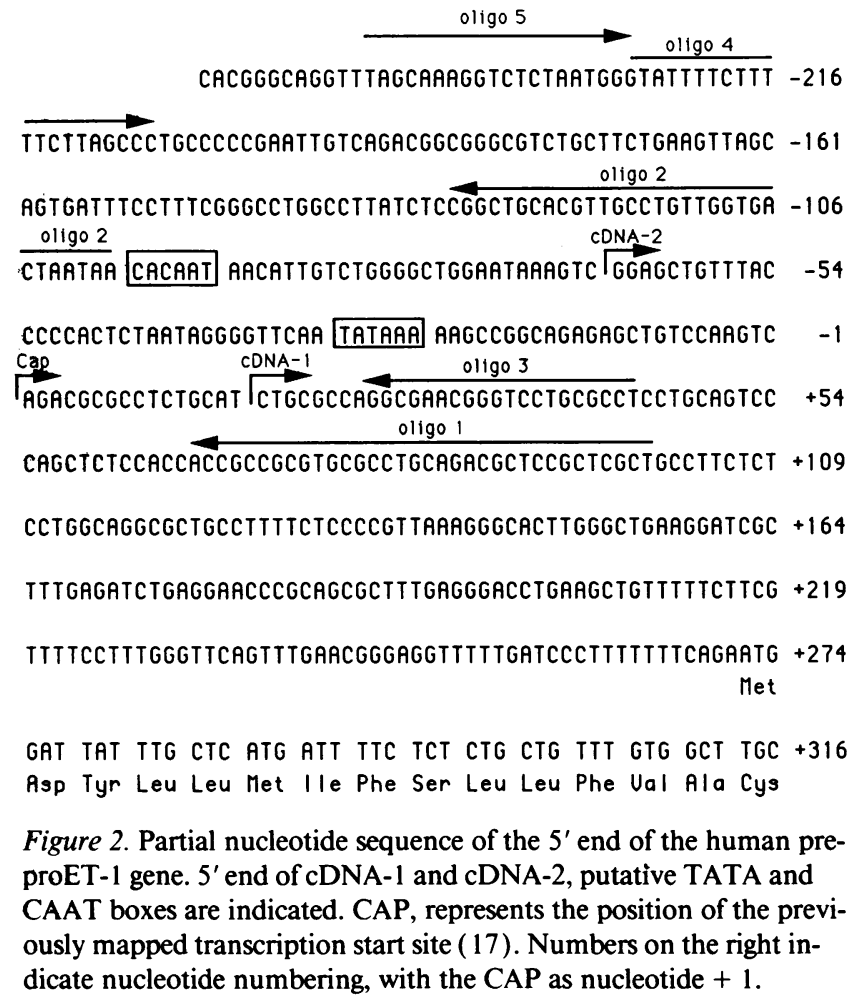

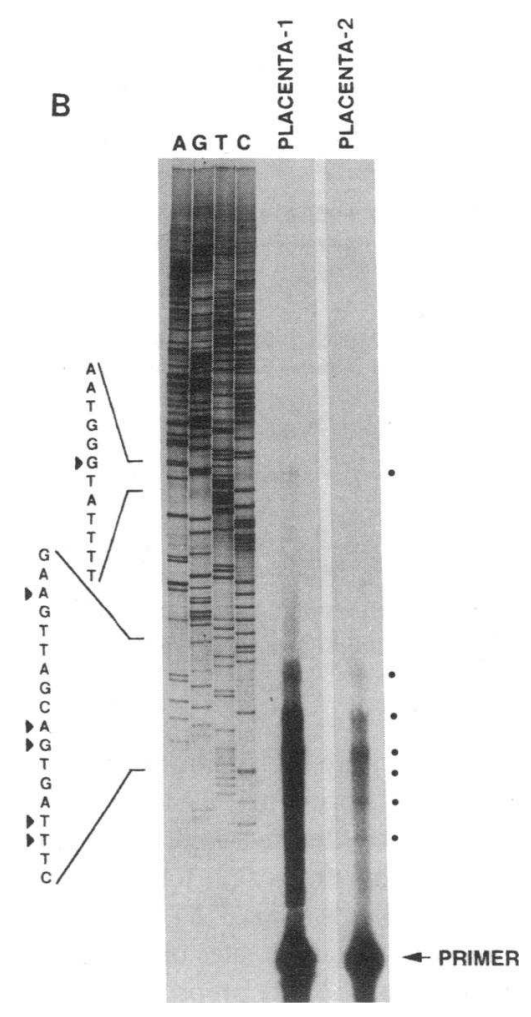

Figure 3. Primer extension of transcription start sites of the human preproET-1 gene. Two antisense primers, panel $A$ : oligo 1, and panel $B$ : oligo 2 , were annealed to $20 \mu \mathrm{g}$ of total placenta RNA as described in Methods. Extension products as well as the sequence ladder derived with oligo $1(A)$ and oligo $2(B)$ were separated on a $6 \%$ polyacrylamide gel and exposed to Amersham MP film at $-70^{\circ} \mathrm{C}$ (Amersham Corp., Arlington Heights, IL). Dots at the right side of $A$ and $B$ indicate preproET1-specific reaction products, whereas arrowheads at the left side of $A$ and $B$ indicate nucleotides identified in preproET-1 mRNAs. $(A)$ lane placenta-1, a fivefold over-exposure of lane placenta- 2 . 


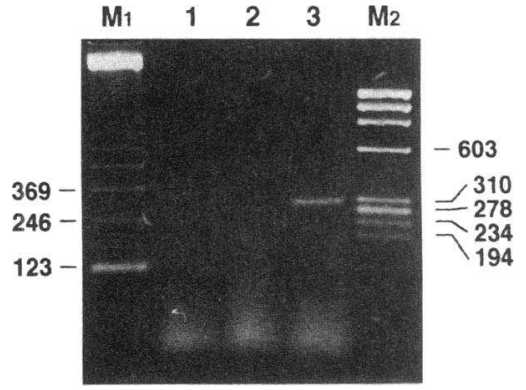

Figure 4. PCR analysis of preproET-1 mRNA cap sites. $2 \%$ agarose gel electrophoresis of the PCR products. Total placenta RNA was reverse transcribed with an oligo $\mathrm{dT}$ primer. First strand cDNA was amplified with two set of primers: oligo 3-4 (lane 3) and oligo 3-5

(lane 2). As control, half of the aliquot of total placenta RNA was pretreated with RNase before reverse transcription and amplified with oligo 3-4 (lane 1). $M_{1}$ and $M_{2}$ represent molecular size standards.

+170 , relative to position +1 of cap- 1 , was fused to the CAT reporter gene in the promoterless expression vector pCAT-Promoter (Promega Corp.), to generate hybrid construct -1505 CAT. Several 5 ' deletion mutants were further obtained using specific primers and the PCR technique (Methods). The chimeric genes were transfected into COS-1 (renal epithelial) cells and assayed for promoter activity comparing CAT expression driven by a series of 5 ' promoter deletion mutants to the CAT expression driven by the full length parental CAT construct $-1505 \mathrm{CAT}$. As shown in Fig. 5, the construct $(-1505 \mathrm{CAT})$ was able to induce a high level of CAT gene expression above the background. The level of CAT was drastically reduced when the deletion was extended to $\mathrm{nt}-647$ (-647CAT). Interestingly, a deletion to $\mathrm{nt}-127$ ( $-127 \mathrm{CAT})$, restored promoter activity, while plasmid -99CAT was associated with only threefold lower CAT activity. Further deletions of the CAAT box (-70CAT) and the TATA box $(-25 \mathrm{CAT})$, reduced CAT expression to the background level. These data indicate the presence of a negative regulatory region
$(-647$ to -127$)$ and two positive regulatory regions $(-1505$ to -647 and -127 to -99 ). Moreover, a small DNA region localized $127 \mathrm{nt}$ upstream to cap-1 is able to allow maximal transcription of CAT in COS-1 cells. Therefore, to verify the existence of a second preproET-1 promoter, the region between $\mathrm{nt}$ -127 and -647 , obtained using specific primers and the PCR technique, was fused to the CAT reporter gene and COS- 1 cells were transfected. As shown in Fig. 6, in this case the level of CAT expression was about one-third that observed for the $-1505 C A T$ construct. Nevertheless, we confirmed the presence of a second preproET-1 promoter upstream to the functional TATA and CAAT boxes.

To analyze the tissue distribution of the two preproET-1 mRNAs primer extension was performed. Oligo 1 (see Fig. 2) was used for extension experiments as well as to obtain the sequence ladder. As shown in Fig. 7 there is a selectivity in the expression of mRNA-1 and mRNA-2. In fact, while in the presence of placenta or kidney RNA (lanes 1 and 2) a series of bands specific for the two mRNAs were detected, extension analysis with heart and brain RNA (lanes 3 and 4, respectively), revealed the existence of only mRNA-2 in these tissues.

preproET-1 cell-type-specific expression. Several types of cultured cells were analyzed by Northern blot hybridization and by RIA to detect ET-1 expression (not shown). Among these, COS-1 (renal epithelial) cells expressed ET-1, while HeLa (epidermoid carcinoma) did not. These cell lines were therefore chosen for transfection to evaluate DNA regions potentially involved in the cell-type specific regulation of preproET-1 gene. In contrast to the high level of CAT expression driven by fusion plasmids -1505CAT, -127CAT, and -99CAT in COS-1 cells, all of them showed weak activity in HeLa cells (not shown). These data indicate that -127CAT contains sequence necessary for preproET-1 expression in renal epithelial cells but not in HeLa cells. To characterize further the functional role of this region, the sequence from $\mathrm{nt}$

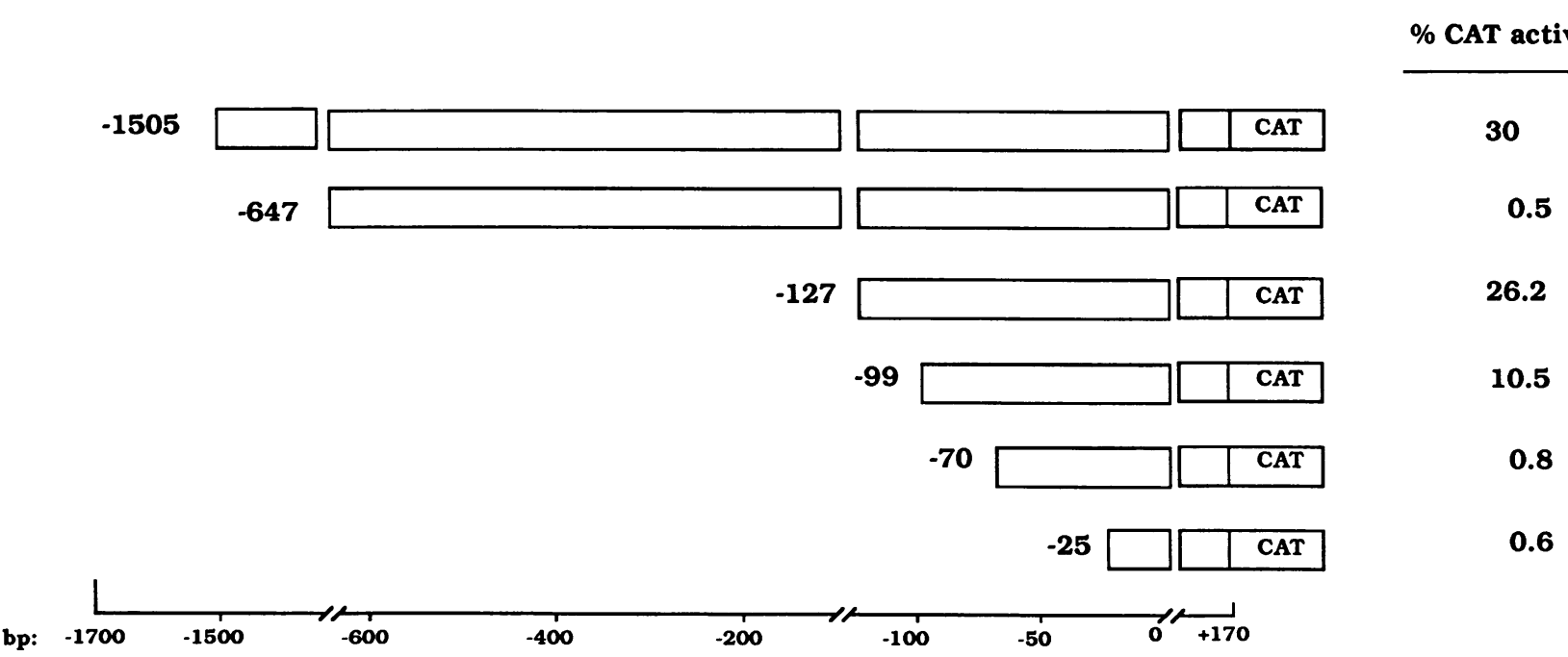

Figure 5. Deletion analysis of the 5'-flanking region of the preproET-1 gene. COS-1 (renal epithelial) cells were transfected with plasmids containing 5'-flanking region of the preproET-1 gene fused to the CAT reporter gene (Methods). Bars represent the fragments of the preproET-1 gene present in each construct. The values are given relative to the CAT activity obtained after transfection with the positive control plasmid pCAT-control (Promega Corp.) which was defined as $100 \%$. The promoterless plasmid pCAT-Basic (Promega Corp.) served as negative control. Results are the mean of three independent transfections. Some experiments were carried out in the presence of the $\beta$-galactosidase reporter plasmid pSV- $\beta$ gal (Promega Corp.). Results obtained in the absence of this plasmid and in its presence and normalized on the basis of its activity were essentially identical. 

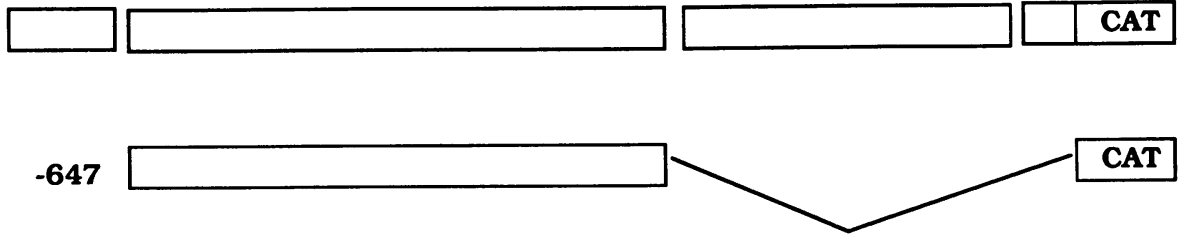

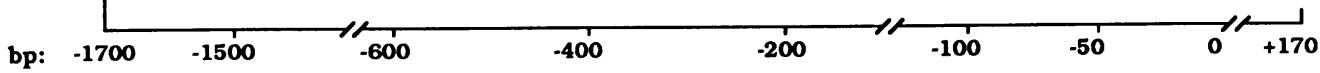

Figure 6. Identification of the preproET-1 upstream promoter. COS-1 (renal epithelial) cells were transfected with a plasmid containing the -647 to -127 preproET-1 5' flanking region fused to the CAT reporter gene. Bars represent the fragment of the preproET-1 gene present in each construct. The values are given relative to the CAT activity obtained after transfection with the positive control plasmid pCAT-Control (Promega Corp.) which was defined as $100 \%$. The promoterless plasmid pCAT-Basic (Promega Corp.) served as negative control. Results are the mean of three independent transfections.

-129 to -40 (including potentially important flanking sequences) was inserted upstream to an heterologous promoter fused to the CAT gene. This construct was used to transfect COS-1 and HeLa cells (Fig. 8). The construct containing the preproET-1 promoter sequence caused an increase in transcription of approximately fourfold in COS- 1 cells; in contrast it did not show enhancement above baseline in the HeLa cells. Therefore we may conclude that we have identified an 89-bp sequence within the preproET-1 downstream promoter necessary for preproET-1 expression at least in renal epithelial cells.

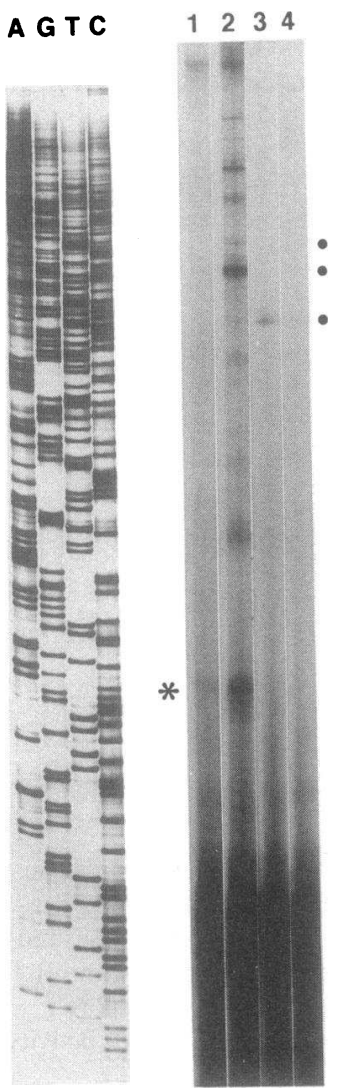

Figure 7. Tissue-specific expression of the two preproET-1 mRNAs. Primer extension analysis was performed as described in Methods, see also Fig. 3 $A$. Asterisk indicates the 5 ' end of mRNA-1 whereas dots indicate the $5^{\prime}$ ends of mRNA-2. Lanes: $1,10 \mu \mathrm{g}$ of placenta RNA; $2,10 \mu \mathrm{g}$ of kidney RNA; 3, $1 \mu \mathrm{g}$ of heart mRNA; 4, $1 \mu \mathrm{g}$ of brain mRNA.

\section{Discussion}

The studies presented here demonstrate for the first time that at least two human preproET-1 mRNAs are produced from a single gene by use of different promoters. From the genomic data it is known that the human preproET-1 gene consists of five exons and four intervening sequences distributed over 6.8 $\mathrm{kb}$ of genomic DNA (17). Northern blot analysis showed that a single 2.3-kb preproET-1 mRNA was expressed in cultured human umbilical vein endothelial cells (15). We describe herein the isolation from a human placenta library of two preproET-1 cDNAs which share the same coding sequence but differ in their $5^{\prime}$-UTR. Heterogeneity at the $5^{\prime}$ end of the human preproET-1 transcripts has not been previously described. Primer extension shows that the shorter preproET-1 mRNA (mRNA-1) originates from a proximal cap site (cap-1), located about $30 \mathrm{nt}$ downstream a TATA consensus sequence. Our results confirm the position of the preproET-1 cap site previously mapped with S1 analysis (17). Several putative transcription initiation sites were also observed upstream to cap-1. PCR analysis further demonstrate that the upstream cap site is not located to an alternative $5^{\prime}$ exon. Therefore, no alternate splicing pattern was observed in the $5^{\prime}$-UTR of preproET1 mRNAs.

Transfection experiment shows that a 127-bp region upstream of cap- 1 that contains CAAT and TATA elements is essential for preproET-1 expression. Surprisingly, these functional regulatory elements were found within the 5'-UTR of mRNA-2. These findings implied that a second promoter could exist in a region upstream to the 5 ' end of mRNA-2. Further transfections with a plasmid containing the 520-bp sequence upstream to the minimal 127-bp preproET-1 promoter region previously mapped, confirmed this hypothesis and indicates that the two preproET-1 promoters can function independently. Moreover, transcriptional analysis of the rat preproET1 gene indicates that the existence of dual promoters specifying alternative preproET-1 transcripts may not be a species-specific mechanism (Benatti, L., unpublished data).

Many genes with alternative promoters have been described (32) but none of them shares common structure with 

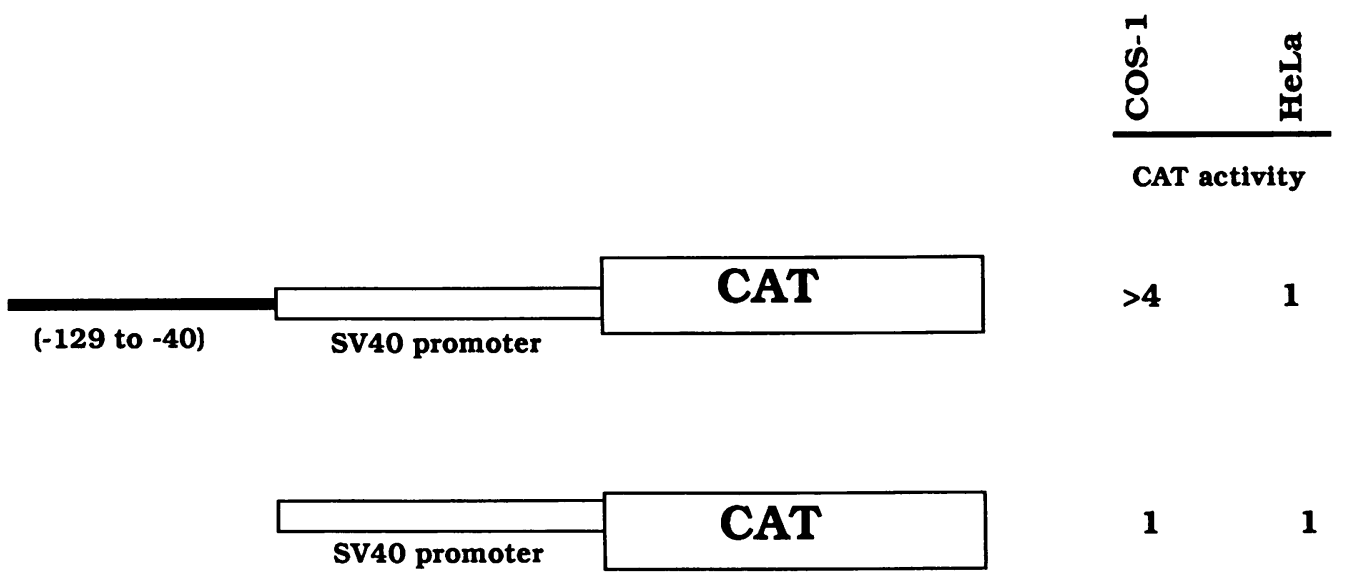

1

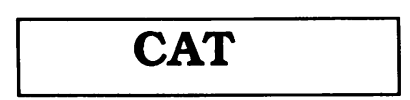

$\mathbf{0}$

Figure 8. Sequence requirement for preproET-1 gene expression. Two 94-bp complementary oligonucleotides having Bgl II linkers at their 5 ' ends and encoding the sequence between $n t-129$ and -40 of the human preproET-1 gene were synthesized. After annealing were inserted into the Bgl II site upstream to the minimal SV40 promoter of the pCAT-promoter plasmid 1 (Promega Corp.). COS-1 and HeLa cells were then transfected with the hybrid construct. The promoterless plasmid pCAT-basic (Promega Corp.) served as negative control, while the pCATpromoter plasmid expressing

the CAT gene under the minimal SV40 promoter served as positive control. Levels of CAT activity obtained with pCAT-promoter were the same either with COS-1 and HeLa cells and were considered as 1. 0 CAT activity refers to the background level. Results are the mean of three independent transfections.

the preproET-1 gene. Therefore, we suggest that the mechanisms of transcription herein described, showing that the same preproET-1 polypeptide is encoded by two different 5 '-extended mRNAs, may represent a novel form of eukaryotic gene organization. In recent years, examples of translational control by the 5'-UTR of an mRNA have been reported (33-35). Because of the striking length of the 5'-UTR of preproET-1 mRNA-2 we have compared in vitro translation of both mRNAs. Our preliminary results suggest a potent inhibition of at least in vitro translation by the $5^{\prime}$-UTR of the longer mRNA form (not shown).

Several mammalian mRNAs are expressed only in specific tissues and initiate at a single site which is found $\sim 30$ bases downstream of a highly conserved promoter region containing TATA and CAAT boxes. While this is what we observed for the preproET-1 downstream promoter region, analysis of the sequence upstream to mRNA-2 reveals no suitable TATA boxes. This could partially explain the presence of putative multiple transcription initiation sites showed by primer extension. In fact, many genes lacking 5' TATA sequences often display heterogeneity of transcript initiation. Interestingly, the upstream promoter region of the preproET-1 gene contains three CAATlike sequences as observed in the case of the upstream promoter of the pyruvate kinase gene (36). To verify whether these sequences have any functional role, deletion and point mutation analysis of this region is under investigation.

Sequence requirement for preproET-1 expression in endothelial cells has been recently investigated (25-27). Two DNA regions were found to be important for constitutive expression of the preproET-1 gene in endothelial cells: region A, located at bp -148 to -117 , and region $B$, located at bp -117 to -98 (25). The emerging role of ET-1 in renal pathophysiology (37) prompt us to investigate the role of cis-acting sequences in preproET-1 expression in the kidney. Recently, we showed that ET-1 is constitutively expressed by mesangial cells and that it is regulated by factors potentially released by inflammatory cells and platelets infiltrating the glomerular tuft during the course of various types of glomerulonephritis (5). Monkey kidney epithelial (COS-1) cells were used for our studies because attempts to transfect mesangial cells were unsuccessful. Using deletion mutants and enhancer trap experiments we have identified an 89-bp region, located at bp -129 to -40 of the preproET-1 gene, necessary for its expression in kidney epithelial cells. These data contrast with those obtained by other authors. Wilson and co-workers, identified a nonerythroid GATAbinding protein which binds to a GATA motif located at bp -135 to -132 , region $\mathrm{A}$, and which is required for preproET-1 promoter function (26). Surprisingly, a deletion mutant $(-127 \mathrm{CAT})$, which excludes this GATA element, is sufficient to drive high level of CAT expression in COS-1 cells. Molecular cloning of the GATA protein (GATA-2) responsible for preproET-1 gene expression in endothelial cells has been recently described (27). Transactivation experiments showed that while GATA-2 was effective at activating reporter constructs carrying region A in endothelial cells, on the contrary it was completely ineffective in COS cells (27). Altogether these data suggest that different mechanisms control preproET-1 gene expression in renal epithelial cells as compared to endothelial cells.

ET-1 has surprisingly potent and wide ranging biological activities. In the last three years, many attempts have been focused to understand the mechanisms controlling the processing of its inactive precursor. Recently, we reported that human preproET- 1 follows the constitutive secretory pathway and undergoes posttranslational polypeptide maturation when expressed in Xenopus oocytes (21). We therefore suggested that regulation of ET-1 secretion occurs mainly at transcriptional level. The data presented herein strengthen this hypothesis. An open question that deserve further investigation is the biological relevance of the tissue-specific expression of mRNA-1 and mRNA-2. Previous observations have indicated that plasma levels of ET-1 in humans are elevated after acute myocardial 
infarction (38). Interestingly, the "acute phase reactant regulatory elements" CTGGGA, thought to mediate the induction of the mRNA under acute physical stress in vivo $(39,40)$, is present in the region mapped as preproET-1 upstream promoter. Moreover, the presence of only mRNA-2 in heart tissue may suggest the existence of specific mechanisms controlling ET-1 gene expression under pathophysiological events such as myocardial infarction.

\section{Acknowledgments}

We thank Dr. M. S. Fabbrini and Dr. A. Galvani for critical reading of the manuscript, Jan Malyszko for the oligonucleotide synthesis and purification, and E. Conti for photographs.

\section{References}

1. Yanagisawa, M., H. Hurihara, S. Himura, Y. Tomobe, M. Hobayashi, Y. Mitsui, H. Goto, and T. Masaki. 1988. A novel potent vasoconstrictor peptide produced by vascular endothelial cells. Nature (Lond.). 332:411-415.

2. Giaid, A., S. J. Gibson, N. Ibrahim, S. Legon, S. R. Bloom, M. Yanagisawa, T. Masaki, I. M. Varndell, and J. M. Polak. 1989. Endothelin 1, an endotheliumderived peptide, is expressed in neurons of the human spinal cord and dorsal root ganglia. Proc. Natl. Acad. Sci. USA. 86:7634-7638.

3. MacCumber, M. W., C. A. Ross, and S. H. Snyder. 1990. Endothelin in brain: receptors, mitogenesis, and biosynthesis in glial cells. Proc. Natl. Acad. Sci. USA. 87:2359-2363.

4. Baley, P. A., T. J. Resink, V. Eppenberger, and A. W. A. Hahn. 1990. Endothelin messenger-RNA and receptors are differentially expressed in cultured human breast epithelial and stromal cells. J. Clin. Invest. 85:1320-1323.

5. Zoja, C., S. Orisio, N. Perico, A. Benigni, M. Morigi, L. Benatti, A. Rambaldi, and G. Remuzzi. 1991. Constitutive expression of endothelin gene in cultured human mesangial cells and its modulation by transforming growth factor $-\beta$, thrombin, and a thromboxane $\mathrm{A}_{2}$ analogue. Lab. Invest. 64:16-20.

6. Komura, I., H. Kurihara, T. Sugiyama, F. Takaku, and Y. Yazaki. 1988. Endothelin stimulates c-fos and c-myc expression and proliferation of vascular smooth muscle cells. FEBS (Fed. Eur. Biochem. Soc.) Lett. 238:249-252.

7. Takuwa, N., Y. Takuwa, M. Yanagisawa, H. Yamashita, and T. Masaki. 1989. A novel vasoactive peptide endothelin stimulates mitogenesis through inositol lipid turnover in swiss 3T3 fibroblast. J. Biol. Chem. 264:7856-7861.

8. Bard, H. F., J. J. Murray, M. D. Breyer, H. Takahashi, T. Inagami, and R. C. Harris. 1989. Mesangial cell, glomerular, and renal vascular responses to endothelin in the rat kidney. J. Clin. Invest. 83:336-342.

9. Simonson, M. S., S. Wann, P. Mene, G. R. Dubyak, M. Haster, Y. Nakazato, J. R. Sedor, and M. J. Dunn. 1989. Endothelin stimulates phospholipase C, $\mathrm{Na}^{+} / \mathrm{H}^{+}$exchange, c-fos expression, and mitogenesis in rat mesangial cells. $J$. Clin. Invest. 83:708-712.

10. Fukuda, Y., Y. Hirata, H. Yoshima, T. Kojima, Y. Kobayashi, M. Yanagisawa, and T. Masaki. 1988. Endothelin is a potent secretagogue for atrial natriuretic peptide in cultured rat atrial myocytes. Biochem. Biophys. Res. Commun. 155:167-172.

11. Shubeita, H. E., P. M. McDonough, A. N. Harris, K. U. Knowlton, C. C. Glembotski, J. K. Brown, and K. R. Chien. 1990. Endothelin induction of inositol phospholipid hydrolysis, sarcomere assembly, and cardiac gene expression in ventricular myocytes. J. Biol. Chem. 265:20555-20562.

12. Takagi, M., H. Matsuoka, K. Atarashi, and S. Yagi. 1988. Endothelin: a new inhibitor of renin release. Biochem. Biophys. Res. Commun. 157:11641168.

13. Pruis, J., and J. J. Emeis. 1990. Endothelin-1 and endothelin-3 induce the release of tissue-type plasminogen-activator and von Willebrand factor from endothelial-cells. Eur. J. Pharmacol. 187:105-112.

14. Lidbury, P. S., C. Thiemermann, R. Korbut, and J. R. Vane. 1990. Endothelins release tissue plasminogen-activator and prostanoids. Eur. J. Pharmacol. 186:205-212.

15. Itoh, Y., M. Yanagisawa, S. Ohkubo, C. Kimura, T. Kosada, A. Inoue, N. Ishida, Y. Mitsui, H. Onda, M. Fujino, and T. Masaki. 1988. Cloning and sequence analysis of cDNA encoding the precursor of a human endothelium-derived vasoconstrictor peptide, endothelin; identity of human and porcine endothelin. FEBS (Fed. Eur. Biochem. Soc.) Lett. 231:440-444.

16. Bloch, K. D., S. P. Friedrich, M.-E. Lee, R. L. Eddy, T. B. Shows, and T.
Quertermous. 1989. Structural organization and chromosomal assignment of the gene encoding endothelin. J. Biol. Chem. 264:10851-10857.

17. Inoue, A., M. Yanagisawa, Y. Takuwa, Y. Mitsui, M. Kobayashi, and T. Masaki. 1989. The human preproendothelin-1 gene. J. Biol. Chem. 264:1495414959.

18. Fabbrini, M. S., B. Valsasina, G. Nitti, L. Benatti, and A. Vitale. 1991. The signal peptide of human preproendothelin-1. FEBS (Fed. Eur. Biochem. Soc.) Lett. 286:91-94.

19. Emori, T., Y. Hirata, K. Ohta, M. Shichiri, and F. Marumo. 1989. Secretory mechanism of immunoreactive endothelin in cultured bovine endothelial cells. Biochem. Biophys. Res. Commun. 169:93-100.

20. Sawamura, T., S. Kimura, O. Shinmi, Y. Sugita, M. Yanagisawa, and T. Masaki. 1989. Analysis of endothelin related peptides in culture supernatant of porcine aortic endothelial cells: evidence for biosynthetic pathway of endothelin1. Biochem. Biophys. Res. Commun. 162:1287-1294.

21. Fabbrini, M. S., A. Vitale, C. Patrono, M. Zamai, F. Vaghi, V. R. Caiolfa, L. Monaco, and L. Benatti. 1991. Heterologous in vivo processing of human preproendothelin 1 into bioactive peptide. Proc. Natl. Acad. Sci. USA. 88:89398943.

22. Benatti, L., L. Cozzi, M. Zamai, M. Tamburin, F. Vaghi, V. R. Caiolfa, M. S. Fabbrini, and P. Sarmientos. 1992. Human preproendothelin-1 is converted into active endothelin-1 by baculovirus-infected insect cells. Biochem. Biophys. Res. Commun. 186:753-759.

23. Leak, L. V. 1980. In Electron Microscopy in Human Medicine. Johannessen, J. V., editor. McGraw-Hill International Book Company, New York. 5:94140.

24. Hahn, A. W. A., T. J. Resink, T. Scott-Burden, J. Powell, Y. Dohi, and F. R. Buhler. 1990. Stimulation of endothelin mRNA and secretion in rat vascular smooth muscle cells: a novel autocrine function. Cell. Regul. 1:649-659.

25. Lee, M.-E., K. D. Bloch, J. A. Clifford, and T. Quertermous. 1990. Functional analysis of the endothelin-1 gene promoter. J. Biol. Chem. 265:1044610450.

26. Wilson, D., D. M. Dorfman, and S. H. Orkin. 1990. A nonerythroid GATA-binding protein is required for function of the human preproendothelin-1 promoter in endothelial cells. Mol. Cell. Biol. 10:4854-4862.

27. Lee, M.-E., D. H. Temizer, J. A. Clifford, and T. Quertermous. 1991. Cloning of GATA-binding protein that regulates endothelin-1 gene expression in endothelial cells. J. Biol. Chem. 266:16188-16192.

28. Davis, L. G., M. D. Dibner, and J. M. Battey. 1986. Basic Methods in Molecular Biology. Elsevier Science Publishing Co., Inc., New York.

29. Ausubel, F. M., R. Brent, R. E. Kingston, D. D. Moore, J. G. Seidman, J. A. Smith, and K. Struhl. 1987. Current Protocols in Molecular Biology. WileyLiss, Inc., New York.

30. Saiki, R. K., D. H. Gelfand, S. Stoffel, S. J. Scharf, R. Higuchi, G. T. Horn, D. B. Mullis, and H. A. Erlich. 1988. Primer-directed enzymatic amplification of DNA with a thermostable DNA polymerase. Science (Wash. DC). 239:487-491.

31. Gorman, C. M., L. F. Moffat, and B. H. Howard. 1982. Recombinant genomes which express chloramphenicol acetyl-transferase in mammalian cells. Mol. Cell. Biol. 2:1044-1051.

32. Schibler, U., and F. Sierra. 1987. Alternative promoters in developmental gene expression. Annu. Rev. Genet. 21:237-257.

33. Parkin, N., A. Darveau, R. Nicholson, and N. Sonenberg. 1988. cis-acting translational effects of the 5' noncoding region of c-myc mRNA. Mol. Cell. Biol. 8:2875-2883.

34. Ratner, L. 1989. Regulation of expression of the c-sis protooncogene. Nucleic Acids Res. 17:4101-4114.

35. Hinnebush, A. G. 1990. Involvement of an initiation factor and protein phosphorylation in translational control of GCN4 mRNA. Trends Biochem. Sci. 15:148-152.

36. Noguchi, T., K. Yamada, H. Inoue, T. Matsuda, and T. Tanaka. 1987. The L-and R-type isozyme of rat pyruvate kinase are produced from a single gene by use of different promoters. J. Biol. Chem. 262:14366-14371.

37. Kon, V., and K. F. Bard. 1991. Biological actions and pathophysiologic significance of endothelin in the kidney. Kidney Int. 40:1-12.

38. Miyauchi, T., M. Yanagisawa, T. Tomizawa, Y. Sugishita, N. Suzuki, M. Fujino, R. Ajisaka, K. Goto, and T. Masaki. 1989. Increased plasma concentrations of endothelin-1 and big endothelin-1 in acute myocardial infarction. Lancet. ii:53-54.

39. Fowlkes, D. H., N. T. Mullis, C. M. Comeau, and G. R. Crabtree. 1984. Potential basis for regulation of the coordinately expressed fibrinogen genes: homology in the 5' flanking regions. Proc. Natl. Acad. Sci. USA. 81:2313-2316.

40. Adrian, G. S., B. W. Korinek, B. H. Bowman, and F. Yang. 1986. The human transferrin gene: $5^{\prime}$ region contains conserved sequences which match the control elements by heavy metals, glucocorticoids and acute phase reaction. Gene (Amst.). 49:167-175. 